\title{
"SANGUE DE PEÃO, ENGORDA BOI DE PAULISTA": A QUESTÃO DO TRABALHO ESCRAVO NA REGIÃO DO BICO DO PAPAGAIO
}

\section{“SANGRE DE PEÃO, BUEY DE ENGORDE DE SÃO PAULO": LA CUESTIÓN DEL TRABAJO ESCLAVO EN LA REGIÓN DE BICO DO PAPAGAIO}

Patrícia Rocha CHAVES ${ }^{1}$

\begin{abstract}
Resumo: Este artigo se trata de parte da pesquisa de doutorado em Geografia Humana, intitulada "Rebeldia e Barbárie: Conflitos Socioterritoriais na região do Bico do Papagaio. Através das ocorrências registradas no Caderno de Conflitos no Campo e de levantamentos documentais organizados pela CPT (Comissão Pastoral da Terra), foram sistematizados e mapeados os variados tipos de conflitos que ocorrem na região - 111 municípios localizados nos estados: Maranhão, Tocantins e Pará. Também foram realizados trabalhos de campo, em comunidades camponesas, assentamentos de reforma agrária, territórios quilombolas e territórios indígenas em 24 municípios, considerados nos anos de 2011 a 2014 os mais densamente conflituosos e violentos. Ao todo, foram produzidos 74 mapas e o resultado foi a proposição conceitual, a qual chamamos de conflitos socioterritoriais e conflitos socioespaciais. Este artigo contém parte deste trabalho. Ele parte do resultado do levantamento de dados referente à questão trabalho escravo ou peonagem na região do bico do papagaio.
\end{abstract}

Palavras-Chaves: Trabalho escravo; Peonagem; Conflitos no campo.

Resumen: Este artículo es parte de la investigación de doctorado en Geografía Humana, titulada "Rebelión y barbarie: conflictos socioterritoriales en la región de Bico do Papagaio. A través de las ocurrencias registradas en el Libro de Conflictos de Campo y las encuestas documentales organizadas por la CPT (Comissão Pastoral da Terra), se sistematizaron y mapearon los distintos tipos de conflictos que ocurren en la región - 111 municipios ubicados en los estados: Maranhão, Tocantins y Pará. También se realizó trabajo de campo en comunidades campesinas, asentamientos de reforma agraria, territorios quilombolas y territorios indígenas en 24 municipios, los cuales fueron considerados los más densamente conflictivos y violentos en los años 2011 a 2014. En total, se produjeron 74 mapas y el resultado fue la propuesta conceptual, que llamamos conflictos socioterritoriales y conflictos socio-espaciales. Este artículo contiene parte de este trabajo. Se parte del resultado de la encuesta de datos sobre el tema del trabajo esclavo o peonaje en la región del Bico do Papagaio.

Palabras Claves: Trabajo esclavo; Peonaje; Conflictos de Campo.

\section{Introdução}

"Peão é só o serviço dele. Sangue de peão, engorda boi de paulista." (Murilo Carvalho,1980)

\footnotetext{
${ }^{1}$ Atualmente é professora Adjunta do curso de Geografia da Universidade Federal do Amapá e professora do Mestrado em Geografia PPGEO - Unifap. Doutora em Geografia Humana pela USP- Universidade de São Paulo; Mestre em Desenvolvimento Regional pela Universidade Federal do Tocantins, possui Graduação em Geografia pela Universidade Federal do Tocantins (2006). Professora do Curso de Especialização em Estudos Culturais e Políticas Públicas da UNIFAP. Pesquisadora do Núcleo de Estudos Urbanos Regionais e Agrários - NURBA, do Grupo Geografia Agrária da USP e do Observatório da Democracia, Direitos Humanos e Políticas Públicas. Coordenadora do Coletivo de Estudos sobre Terra e Território na Amazônia. Possui experiências em pesquisa e extensão nas áreas de Geografia Agrária, Movimentos Socioterritoriais, Geografia Política e Econômica da Amazônia. E-mail - patriciarchaves@ hotmail.com
} 
No Brasil, um dos maiores enfrentamentos dos camponeses e entidades que os apoiam tem se dado na luta contra o trabalho escravo, conflito que se concentra especialmente na Amazônia brasileira e progressivamente, na região do Bico do Papagaio.

Sabe-se que a abertura da mata para formação das fazendas de gado nesta região foi, e ainda é realizada pelos peões trazidos dos vários estados brasileiros, em sua maioria da região nordestina. São, via de regra, maranhenses, piauienses, cearenses e baianos que deixam seus lugares de origem por conta da insipiência de trabalho e aumento do número de integrantes das famílias, o que acaba gerando necessidades de sobrevivência que não são sanadas em suas terras, em suas regiões. Assim, dizem “a posse é pequena demais pra tanto braço”, e isso torna-os presas fáceis para o trabalho escravo em terras distantes.

Por conta da dificuldade de encontrar trabalho nos seus lugares originários, aventuram-se pela Amazônia. Essas pessoas são seduzidas por discursos que reproduzem uma imagem incondizente com a realidade sobre a Amazônia. Esses discursos transmitem a ideia de que a região é um grande vazio populacional, e que, por isso, é local aberto às conquistas, havendo ali uma promoção do desenvolvimento.

Dados do Ministério do Trabalho e da Comissão Pastoral da Terra denunciam que boa parte desses trabalhadores são levados a morte, seja pelo fato de estarem subordinados ao trabalho exaustivo, ou pelas condições de abuso e de ausência de infraestrutura das fazendas das quais são recrutados para trabalharem costumeiramente, tais condições os levam à morte, ao "desaparecimento". Em entrevista realizada por Carvalho (1980) obteve-se o seguinte relato:

\begin{abstract}
Na mata a gente sofre demais, maltrata muito o corpo. E bem que não se ganha quase, porque tudo é demais de caro no barracão; arroz é vinte cruzeiros o quilo; feijão é oitenta. Pinga eles não gostam que beba, a gente tem que esconder a garrafa e paga até uns trinta cruzeiros. Agora, como é que peão vai ficar dois, três meses na mata sozinho, na flor da força, sem mulher e sem cachaça? Todo mundo fala que peão na derrubada é bicho encrenqueiro, vive caçando treta, mas, é isso mesmo, na merda, sem nada, ele tem mais é que brigar por qualquer coisa. Ninguém pergunta se peão é gente, é homem. É só o braço dele no machado, no terçado, na moto-serra. Peão é só o serviço, dele, sangue de peão, engorda boi de paulista. (CARVALHO, 1980, p.30)
\end{abstract}

Segundo Carvalho (1980), pode-se verificar uma relação de solidariedade entre os peões. São movidos por grande esperança de melhorar suas vidas.

Ainda bem que a gente sempre acha uma mão, um peão que nem a gente que reparte ajuda. Agora está tudo bem certo. A gente comeu, bebeu e garantiu a 
condução até a barragem. Só falta o emprego dar certo. Eu acho que vai ser até bonito trabalhar de junto daqueles tratorzão danado. Quem sabe a gente até aprende a dirigir um." O outro peão retrucou:" - Isso é ilusão Raimundinho, deixa de bestar." Félix fala rindo, a cara de menino sem nenhum sinal de barba. E peão vive de que, se não é ilusão mesmo, seu moleque?" (CARVALHO, 1980, p.30-31)

Na mesma obra, encontramos a história de Lourival, peão que trabalhou em várias fazendas no município de Santana do Araguaia e que amputou os dedos do pé em frente ao Sindicato de Trabalhadores Rurais de Santana do Araguaia com uma faca e um litro de álcool porque não tinha condições de pagar o médico.

"Ele teve que usar a regra do peão, que nem sangrar boi, porque peão aqui é assim, vale menos que um boi.", afirmou Natal, presidente do STR de Santana do Araguaia, em entrevista a Carvalho (1980). Depois de cortar os dedos Lourival contou ao jornalista, como ele havia chegado àquela situação em que se encontrava:

Já trabalhei nessas Fazendas tudo aí. Codespar, Volksvagem, desde o começo. Já andei por esses matos tudo. Agora, eu era peão na Ecisa, essa firma que tá fazendo a estrada pro Xingu, eu ia nas derrubadas, na frente. E foi que desde março nós não recebia nada, o gato diz que pegava dinheiro da firma e não pagava nóis e foi apertando porque a gente não tinha nem dinheiro pro fumo e tudo que comprava era pra fazer mais dívida. Então, como eu fiquei doente e não tinha jeito, resolvi vir embora e tinha que tirar 2 $\mathrm{km}$ a pé, nas picadas de mata. Saí e quando era com cinco léguas a maleita me pegou e eu fui tropeçando e machuquei os dedos. Já tinha um arranhão feio aí arruinou. Aí eu não aguentava mais quando achei o barracão do Pedro Coleto, na mata e ele me agasalhou lá cinco dias até o febrão baixar. Mas, o pé só piorava, ia inchando, e eu naquela febre não tinha nem um comprimido pra nada e, então, pra aliviar aquela dor, eu achei um pouco de ácido de bateria e derramei no pé, de desespero. Ele comeu muito a carne, e a dor, depois melhorou, ficou até os ossos aparecendo. Mas, aí, eu aguentei. Vim andando até bater na capelinha e caí de novo, que a maleita era braba. Agora que eu fui ao médico, ele cobrava 2200 cruzeiros para torar o pé que ele disse que precisava, mas só torava se eu levasse avalista ou pedisse emprestado. CARVALHO, 1980, p.35)

Esse é apenas um, dentre tantos casos, que explica o alto índice de trabalho escravo, de registros de superexploração e desrespeitos trabalhistas que ocorreram e ainda ocorrem na região. O trabalho escravo é um dos custos sociais do processo de modernização da Amazônia brasileira. Embora haja grande concentração nessa região, há certa divisão regional do trabalho escravo no Brasil.

Este artigo é parte da análise de dados dos registros de ocorrência de Trabalho Escravo nesta região, de 1985, ano da primeira publicação elaborada pela Comissão Pastoral da Terra, à 2014, data da última publicação dos dados que essa pesquisa analisou. 


\section{O Trabalho Escravo ou Peonagem}

Além dos conflitos por terra, ocupações e retomadas, formam o corpus teórico dos levantamentos de dados da CPT: os conflitos trabalhistas, trabalho escravo, superexploração, conflitos pela água, conflitos em tempos de seca, conflitos em área de garimpo e conflitos sindicais. O aporte teórico do conceito de trabalho escravo construído pela CPT foi alterado pelo orientador e autora desta tese:

Conflitos Trabalhistas compreendem os casos em que a relação trabalho Vs. capital indicam a existência de trabalho escravo, superexploração. ( $\mathrm{Na}$ compreensão do que é Trabalho Escravo, a CPT segue o definido pelo artigo 149, do Código Penal Brasileiro, atualizado pela Lei $\mathrm{n}^{\circ} 10.803$, de 11.12.2003, que o caracteriza por submeter alguém a trabalhos forçados ou a jornada exaustiva, ou por sujeitá-lo a condições degradantes de trabalho, ou quando se restringe, por qualquer meio, sua locomoção em razão de dívida contraída com o empregador ou preposto, ou quando se cerceia o uso de qualquer meio de transporte por parte do trabalhador, com o fim de retê-lo no local de trabalho ou quando se mantém vigilância ostensiva no local de trabalho ou se apodera de documentos ou objetos pessoais do trabalhador, com o fim de retê-lo no local de trabalho. As situações de Superexploração acontecem na esfera salarial e dizem respeito às ocorrências em que as horas de trabalho não pagas, excedem a taxa normal de exploração do trabalho. Geralmente estes casos estão ligados a precárias condições de trabalho e moradia. (Cadernos de Conflitos no Campo, 1985-2014)

O Estado brasileiro, ao criar os projetos de avanço do capitalismo na Amazônia, construiu possibilidades econômicas e sociais para que as empresas de capital nacional e internacional se especializassem e reproduzissem tais condições no Brasil. O Estado também incentivou a migração de camponeses e peões, possibilitando não somente a exploração da renda fundiária/natureza, mas também a exploração da mão de obra.

Vejamos o que os registros da CPT nos mostram em relação à questão no gráfico 1 a seguir. 
Gráfico 1 - Brasil: Região do Bico do Papagaio (1985-2014).

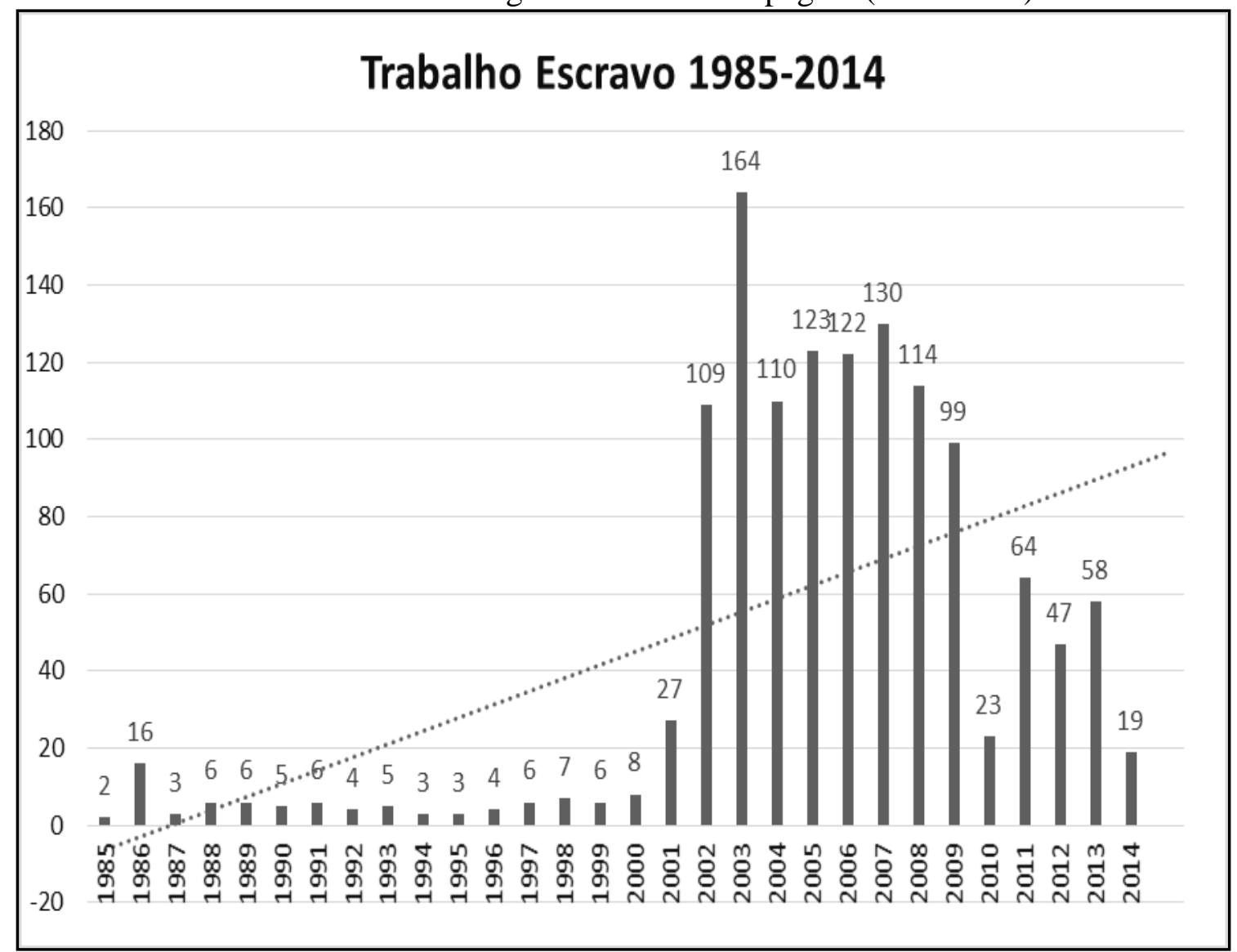

Fonte: Cadernos de Conflitos do Campo (1985-2014) Centro de Documentação Dom Tomás Balduído, CPT.Org: Chaves, R. Patrícia.

Observa-se, em primeiro lugar, que os registros de ocorrências a partir do início deste século tiveram uma grande elevação em relação aos primeiros 15 anos de registros, especialmente entre os anos de 2002 e 2009. Em segundo lugar, é preciso considerar que esses números devem ser observados a partir de contextos políticos.

É preciso explicar que os registros de trabalho escravo e superexploração começaram a ser publicados nos Cadernos de Conflitos no Campo no ano de 1992. Os dados anteriores (1985 a 1995) foram fornecidos pela Comissão Pastoral da Terra, a partir de seus registros preservados em seus arquivos históricos. Assim, entre 1995 e 2014, registrou-se 3.266 ocorrências de trabalho escravo no Brasil, sendo 1.255 relacionadas aos municípios da região do Bico do Papagaio. A região deteve 38,5\% de ocorrências de trabalho escravo.

A partir do número de pessoas envolvidas, conforme o gráfico 2, podemos fazer algumas observações. 
Gráfico 2 - Brasil: Região do Bico do Papagaio (1985-2014).

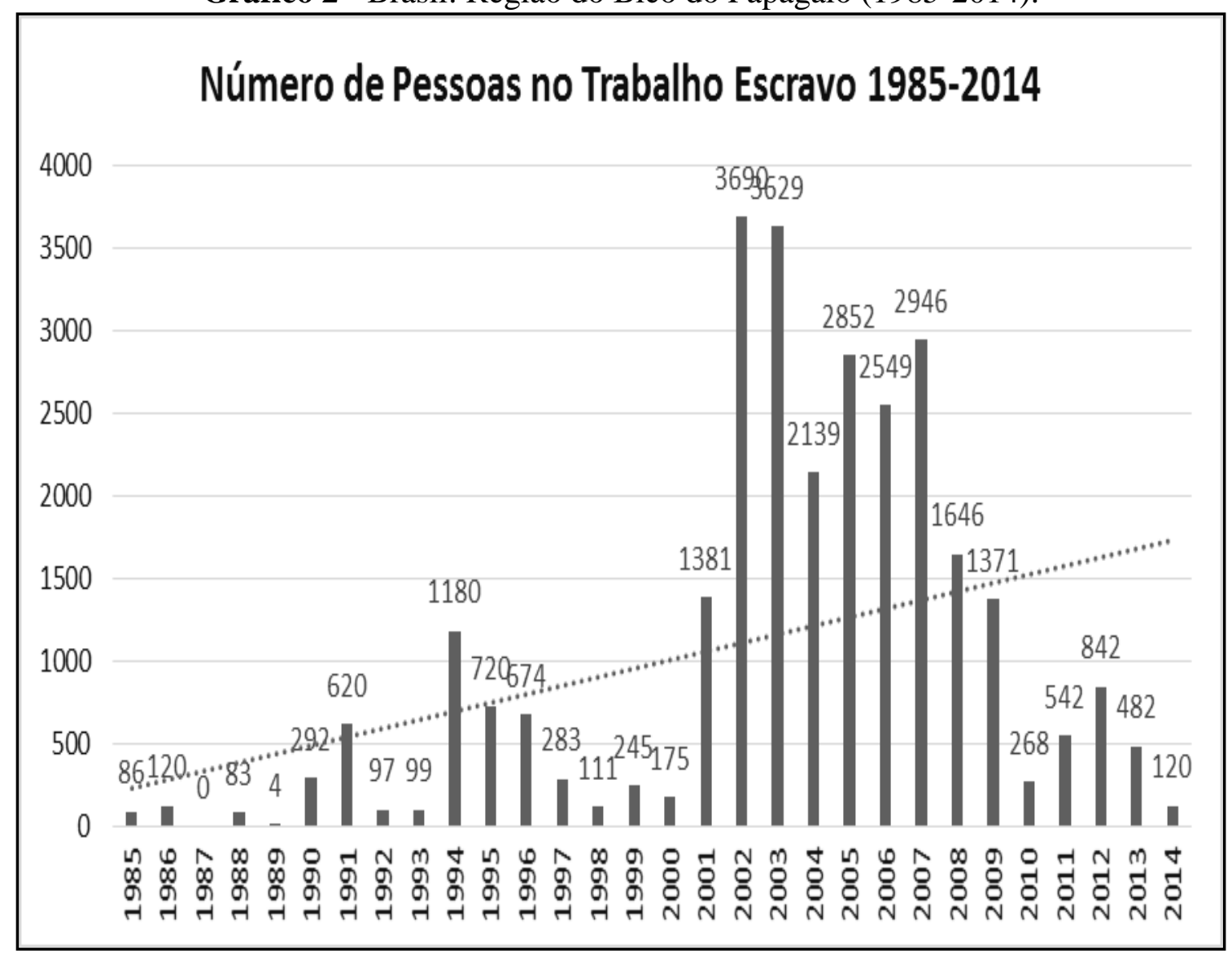

Fonte: Cadernos de Conflitos do Campo (1985-2014) Centro de Documentação Dom Tomás Balduído, CPT.Org: Chaves, R. Patrícia

Nesse período, foram 28.041 pessoas identificadas em 1.255 ocorrências de trabalho escravo no Bico do Papagaio. Consta-se que, no Brasil, foram 87.617 pessoas encontradas nessas condições, nas 3.266 ocorrências de 1992 e 2014. Isto significa dizer que o percentual de pessoas encontradas sob essas condições equivaleu a 32\% do total de todo Brasil. Observase no mapa 1 adiante, a situação do conflito no período de governo de José Sarney (19851989).

Observa-se, também, que os principais municípios com registros de ocorrências foram: São Félix do Xingu, Santana do Araguaia e Redenção. Em seguida, os municípios de Paragominas, Xinguara, Parauapebas, e Bom Jesus das Selvas no Maranhão. 
Mapa 1 - Ocorrência de trabalho escravo no campo durante o governo Sarney.

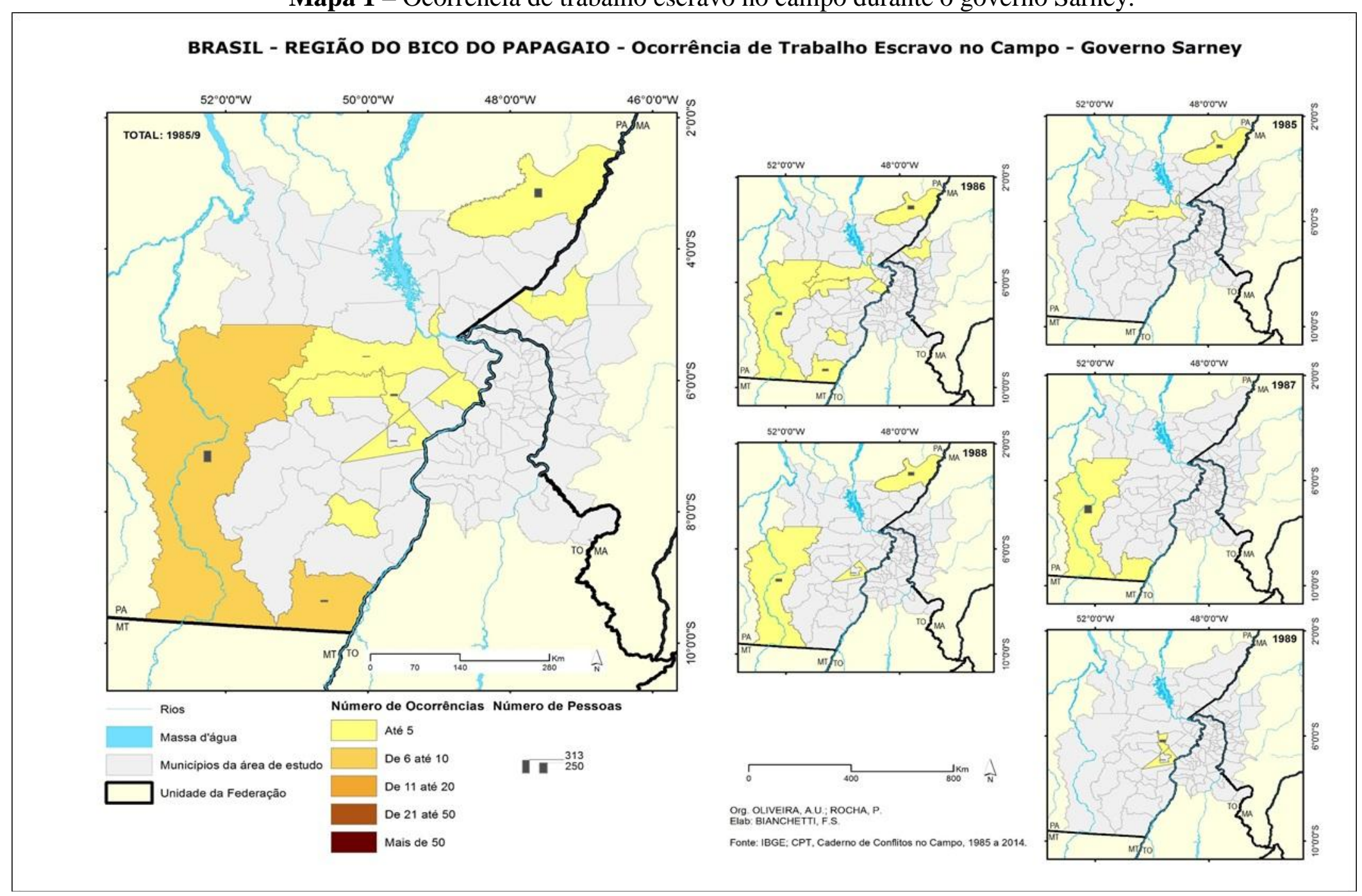


Nos anos do governo Collor/Itamar, as ocorrências de trabalho escravo repercutiram a seguinte dinâmica: 75 ocorrências de trabalho escravo, das quais 12 foram na região do Bico do Papagaio. Em relação ao número de pessoas, 61.575 pessoas em ocorrências de trabalho escravo no Brasil, sendo 1.376 na região do Bico do Papagaio.

Observando o gráfico 2 anterior, podemos verificar que os anos de concentração de maior número de pessoas encontradas em trabalho escravo no período, foram: o ano de 1991, 620 pessoas e 1994 com 1.180 pessoas. O ano de 1990 também registrou um número elevado: 242 pessoas. O número de ocorrências nesses períodos, eram, em média, de três a quatro, todavia, o trabalho escravo tem a característica de aglutinar um número elevado de trabalhadores em uma fazenda ou certo tipo de serviço.

No mapa 2 a seguir, podemos observar também os municípios que apresentaram ocorrências de trabalho escravo no período Collor/Itamar.

Observa-se que no período, os registros mostram que o trabalho escravo estava presente em pelo menos 16 municípios da região. O município de São Felix do Xingu apresentou o maior número de pessoas envolvidas. Xinguara também concentrou um grande número de trabalhadores nesta situação, aproximadamente 100 pessoas.

No gráfico 3 é possível observar a dinâmica do trabalho escravo no período FHC.

Gráfico 3 - Brasil: Região do Bico do Papagaio (1995-2002).

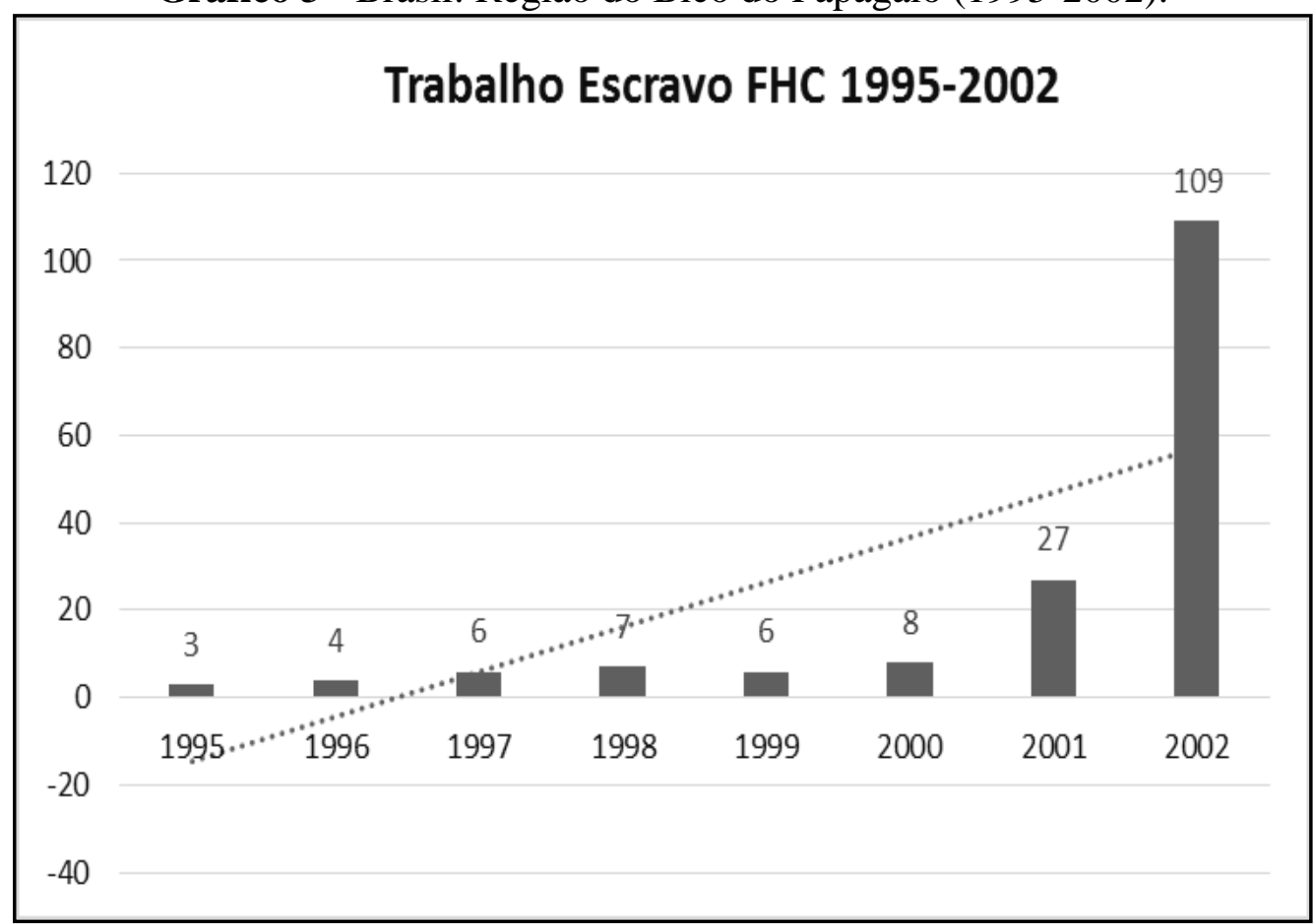

Fonte: Cadernos de Conflitos do Campo (1995-2002) Centro de Documentação Dom Tomás Balduído, CPT.Org: Chaves, R. Patrícia 
Mapa 2 - Ocorrência de trabalho escravo no campo durante o governo Collor/Itamar.

BRASIL - REGIÃO DO BICO DO PAPAGAIO - Ocorrência de Trabalho Escravo no Campo - Governo Collor/Itamar
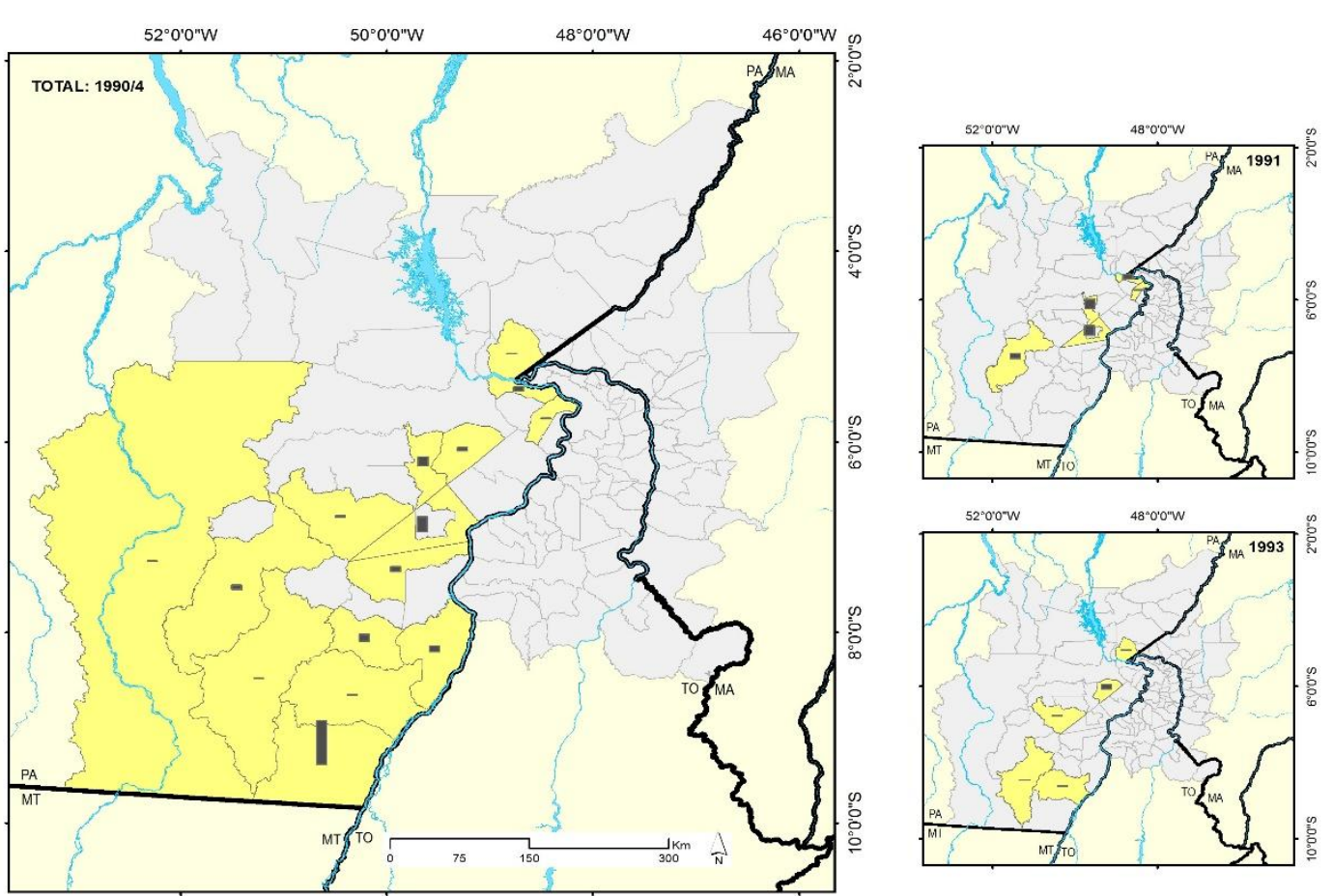

$$
{ }^{52 \% 00 \%}
$$

$48^{4000 \mathrm{~W}}$

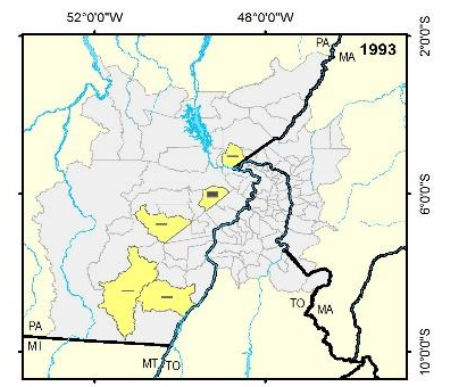

Rios

Número de Ocorrências Número de Pessoas

Massa d'água $\square$ Até 5 De 5 té 10

I $\begin{gathered}1.000 \\ -500 \\ -100\end{gathered}$

Unidade da Federação

De 11 até 20

De 21 até 50

Mais de 51
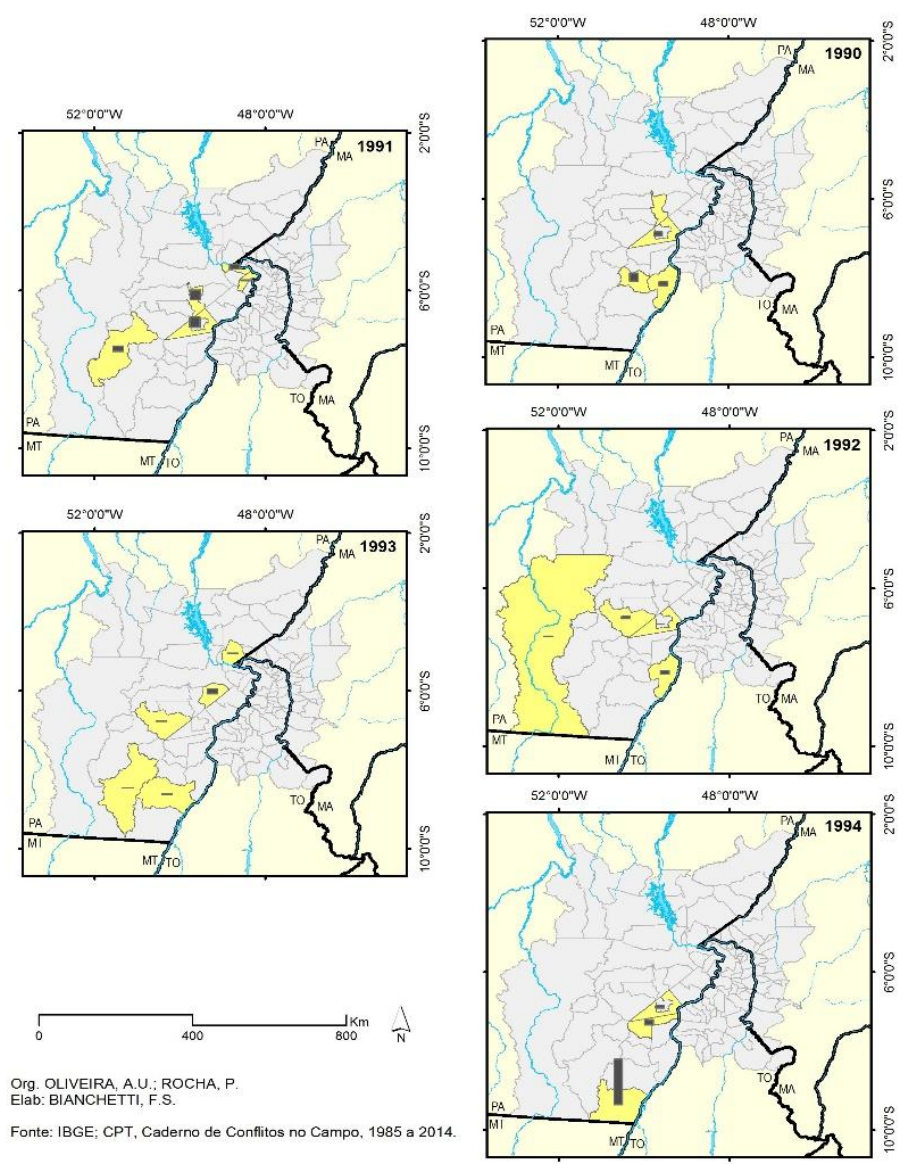
O ano de maior volume de ocorrências foi o de 2002, com 109 ocorrências. O ano de 2001 apresentou 27 ocorrências, o que mostra que a tendência do trabalho escravo nesse governo foi de ascensão constante. No Brasil, foram 219 ocorrências no total, e 170 na região do Bico do Papagaio. Isto significa que 77,6\% das ocorrências de trabalho escravo no período de 1996 a 2002, agrupou-se nesta região. No gráfico 4, vemos o demonstrativo do número de pessoas.

Gráfico 04 - Brasil: Região do Bico do Papagaio (1995-2002).

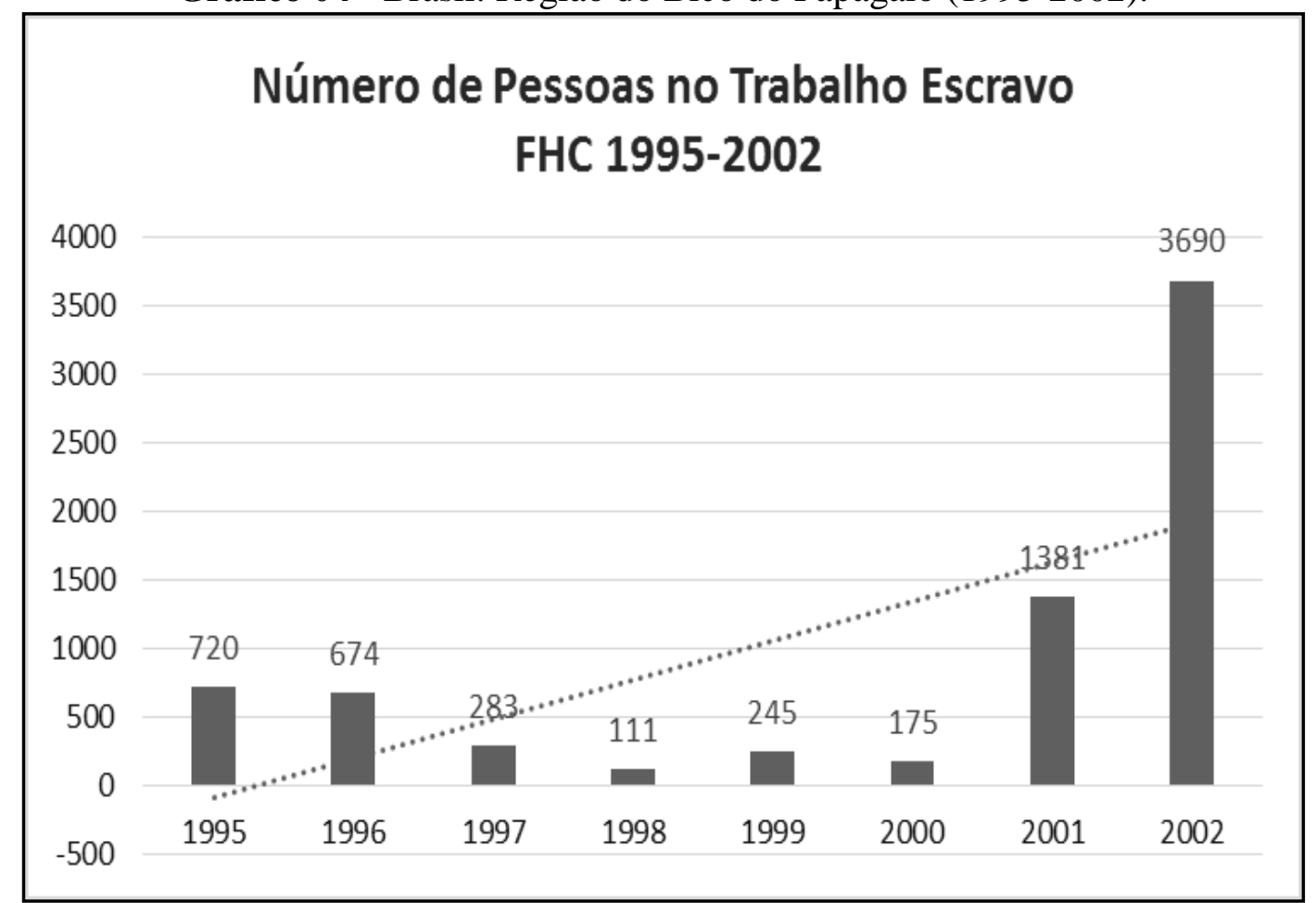

Fonte: Cadernos de Conflitos do Campo (1995-2002). Centro de Documentação Dom Tomás Balduído, CPT.Org: Chaves, R. Patrícia.

O gráfico 4 mostra que no primeiro período deste governo, de 1995 até 1998,o comportamento da curva foi ascendente, apresentando nos dois primeiros anos 720 e 672 pessoas em trabalho escravo. No mandato seguinte - o último ano do governo - o número quadruplicou: de 720 do primeiro estendeu-se para 3.690. Assim, os dados também mostram uma tendência crescente no número de pessoas envolvidas em trabalho escravo no governo FHC. O mapa 3 a seguir, mostra a distribuição do trabalho escravo na região do Bico do Papagaio neste governo.

No período do governo FHC, o número de municípios com ocorrências dobrou. Destacaram-se Bom Jesus das Selvas, Marabá e Santana do Araguaia. Este último município apresentou o maior número de pessoas envolvidas, 1.436 no total. 
Mapa 3 - Ocorrência de trabalho escravo no campo durante o governo FHC.

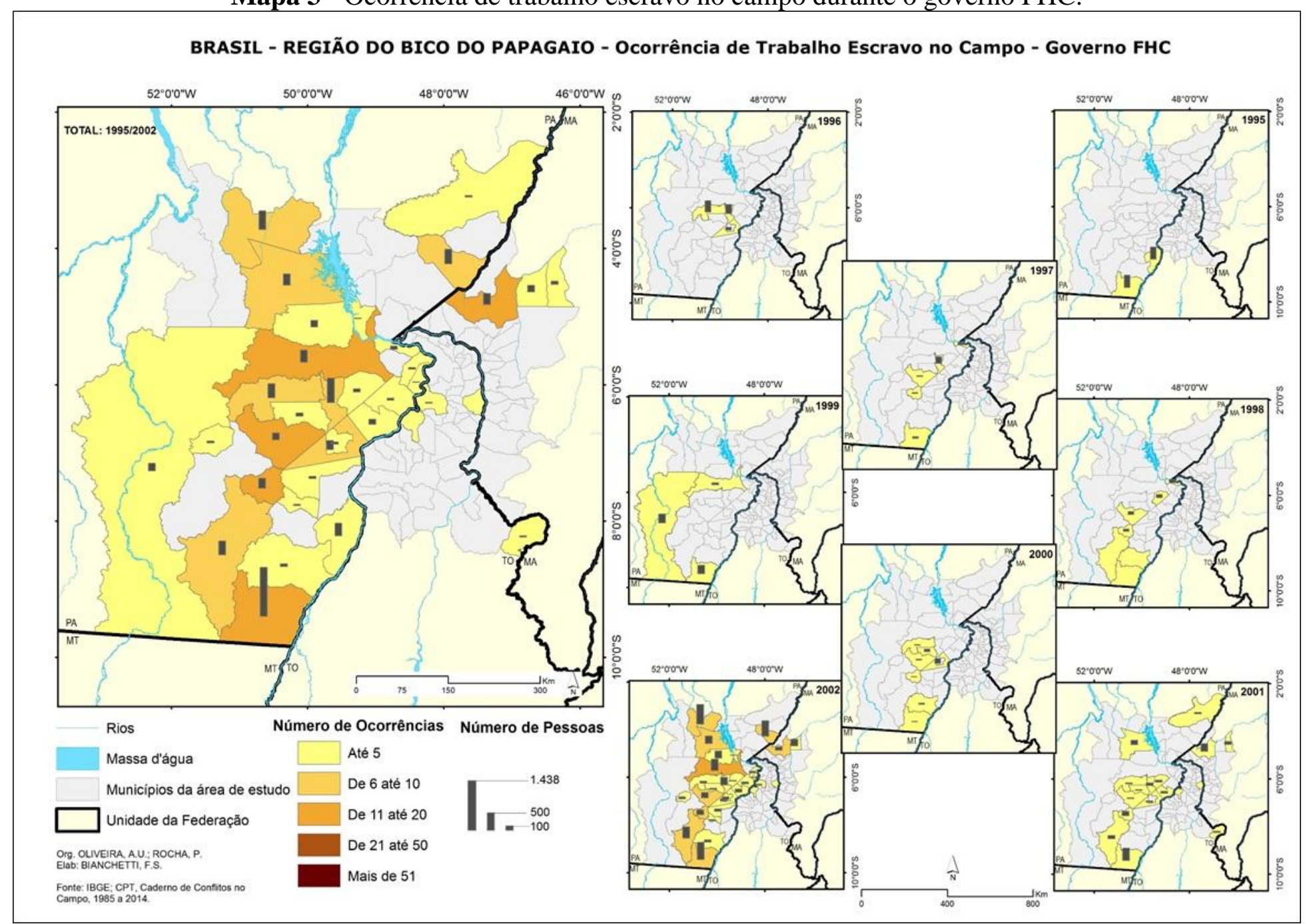


No período de governo do PT, observa-se uma menor elevação nos registros ocorrências e pessoas envolvidas em trabalho escravo. Vejamos o gráfico 5 a seguir:

Gráfico 5 - Brasil: Região do Bico do Papagaio (2003-2014).

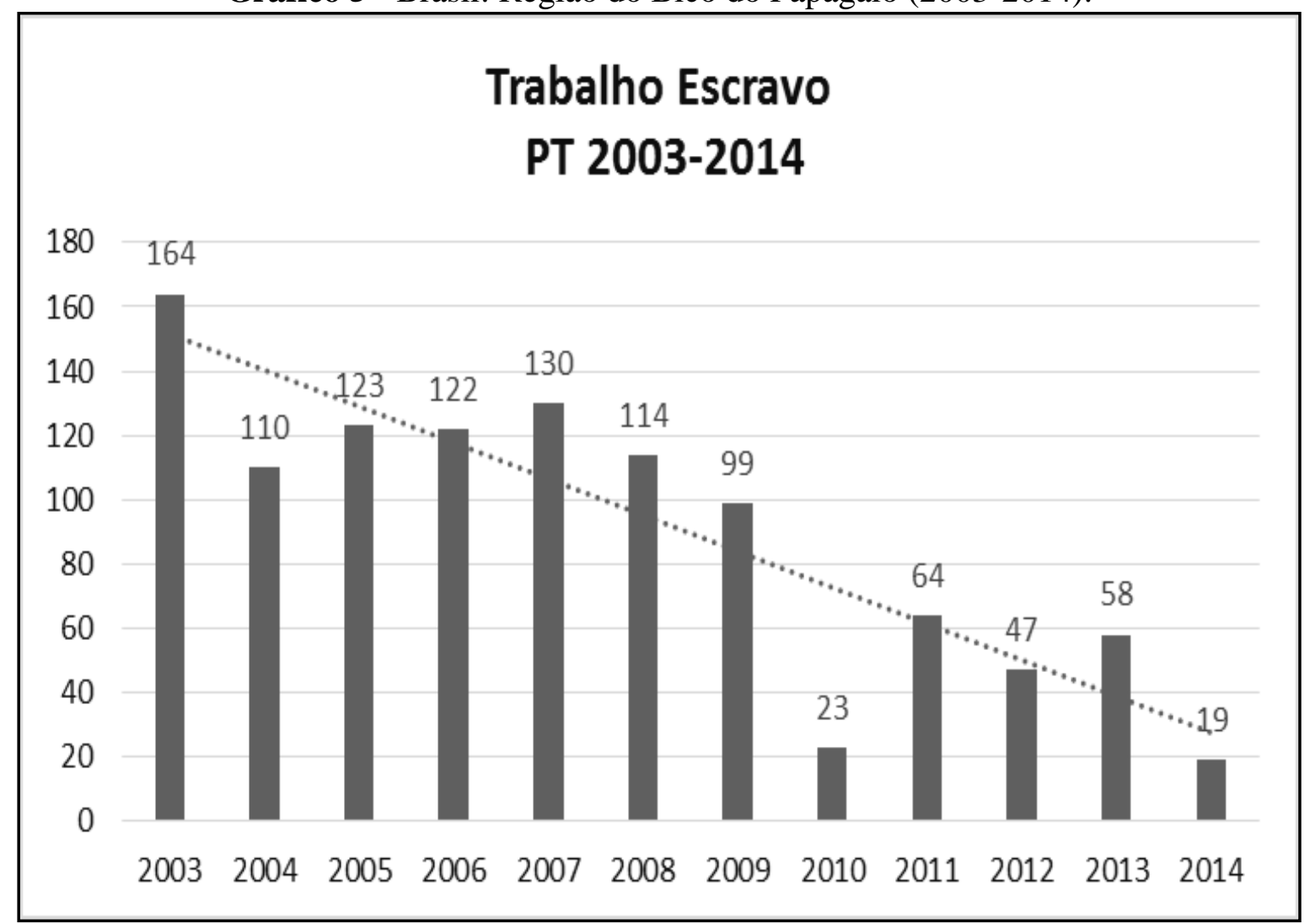

Fonte: Cadernos de Conflitos do Campo (2003-2014) Centro de Documentação Dom Tomás Balduído, CPT.Org: Chaves, R. Patrícia.

Observa-se que, em 2003, apresentou-se menor número de ocorrências de trabalho escravo na região do Bico do Papagaio. Nos anos seguintes, até o ano de 2009, ocorreram em média 100 a 125 ocorrências por ano. Deve ser destacado que esta média subiu entre 2004 e 2007 no governo de Luís Inácio. No primeiro período do mandato de Dilma Rousseff os números de ocorrências diminuíram. No primeiro ano de seu mandato, foram 64 ocorrências de trabalho escravo e nos anos seguintes observa-se certa redução.

A redução de ocorrências de trabalho escravo nesse período deve-se especialmente à atenção de entidades que se disponibilizaram a construir um processo de conscientização em favor das vítimas de trabalho escravo. A CPT, juntamente com grupos de direitos humanos e o Ministério do Trabalho se dedicaram a divulgar na mídia o risco social desse tipo de relação trabalhista. Observa-se uma maior atenção no sentido de registrar, denunciar e fiscalizar o trabalho escravo no Brasil.

Na região do Bico do Papagaio, a CPT Araguaia - Tocantins, localizada em Araguaína 
- TO, assim como as CPTs das demais localidades da região do Bico do Papagaio,preocuparam-se e agiram cotidianamente no combate ao trabalho escravo. Cobram das autoridades, organizam campanhas e debates para uma maior conscientização. Tal trabalho tem sido muito importante na região.

Nos 12 anos de governo do PT, o total de ocorrências de trabalho escravo em todo Brasil foi de 2.670 ocorrências, e, na região do Bico do Papagaio foram 1.073 ocorrências. Portanto, apesar de todos os esforços das várias entidades que se propuseram a combater o trabalho escravo, foram $40,1 \%$ de registros desse tipo de conflito na região.

Analisamos o número de pessoas encontradas nessas situações, conforme disposto no gráfico 6:

Gráfico 6 - Brasil: Região do Bico do Papagaio, número de pessoas em situação de trabalho escravo (2003-2014).

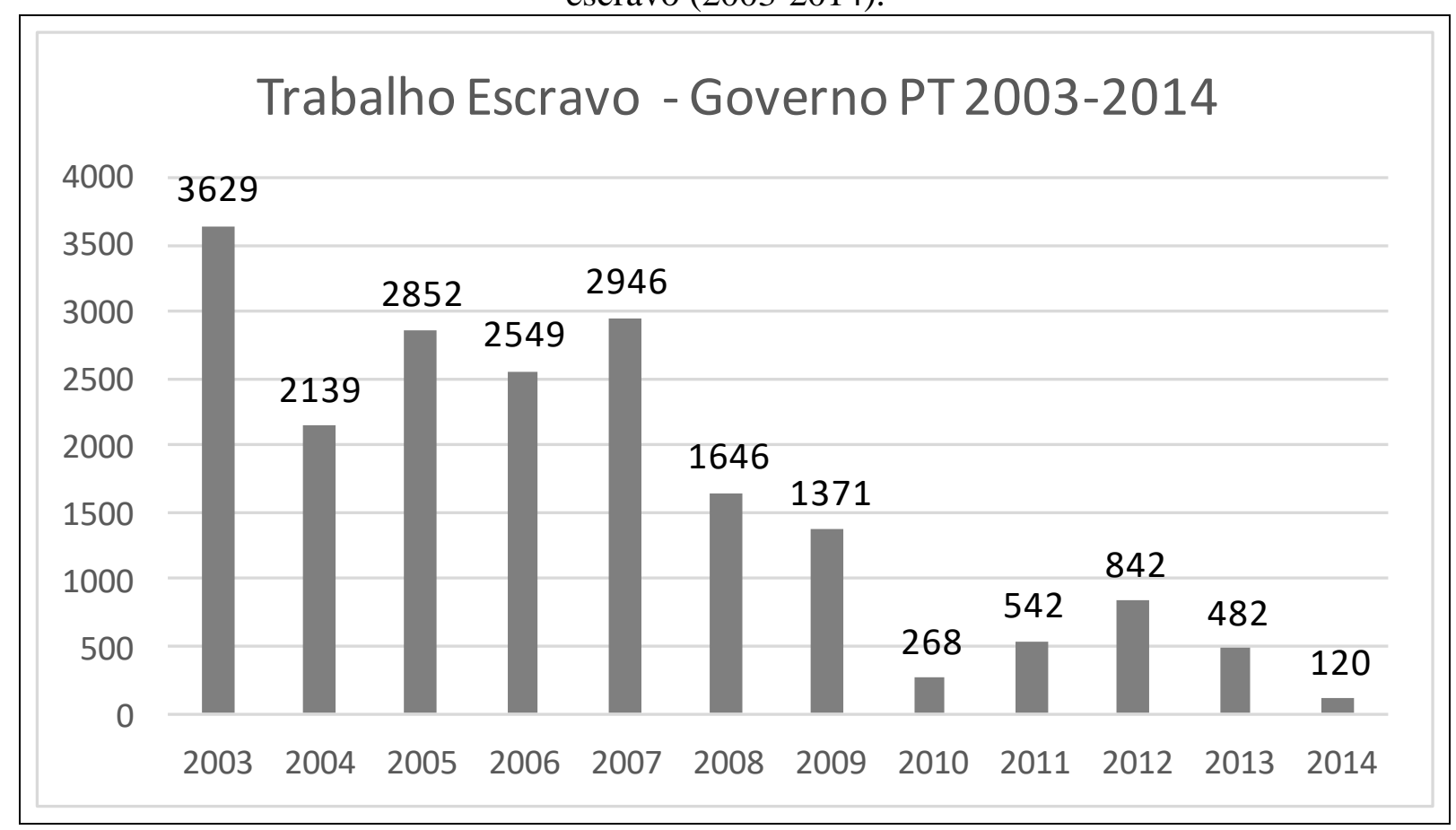

Fonte: Cadernos de Conflitos do Campo (2003-2014) Centro de Documentação Dom Tomás Balduído, CPT.Org: Chaves, R. Patrícia.

Do último ano do Governo FHC, 2002, ao primeiro de Luís Inácio, 2003, houve uma pequena redução no número de pessoas registradas em situação de trabalho escravo: de 3.690 para 3.629. Assim, como no gráfico do número de ocorrências, nos demais anos de seu governo até a chegada do governo de Dilma, houve redução gradativa do número de pessoas em registro.

Nos 12 anos de governo do PT, foram 81.514 pessoas registradas em situação de trabalho escravo no Brasil, sendo 19.286 ocorrências na região do Bico do Papagaio. Um doi.org/10.48075/geoq.v13i5.27159 
número bastante elevado quando comparado aos demais registrados em todo país.

O mapa 4, o do Trabalho Escravo no governo Luís Inácio nos permite observar a distribuição do trabalho escravo nos municípios dessa região, nos anos de 2003 à 2010. No mapa 5 a seguir, vemos a localização do trabalho escravo no período de Dilma, de 2011 à 2014.

No período do governo Luís Inácio, observa-se que São Felix do Xingu, Pacajá, Novo Repartimento, Itupiranga, Rondon do Pará e Xinguara foram municípios com uma grande concentração de ocorrências e grande número de pessoas envolvidas. São vários os municípios do Maranhão, com destaque ainda para o município de Bom Jesus das Selvas. O mesmo ocorreu no estado do Tocantins.

Pelo que se pode observar foram 95 municípios da região que apresentaram ocorrências de trabalho escravo nesse período.

Ainda no mapa 06, referente ao período de Dilma Rousseff, verifica-se uma redução no número de municípios com registros da presença de trabalho escravo, 73 ao todo. Ainda assim, pode-se constatar que o trabalho escravo é na atualidade um dos conflitos sociais que mais tem agigantado sobre os camponeses expropriados na região. 
Mapa 4 - Ocorrência de trabalho escravo no campo durante o governo Lula.

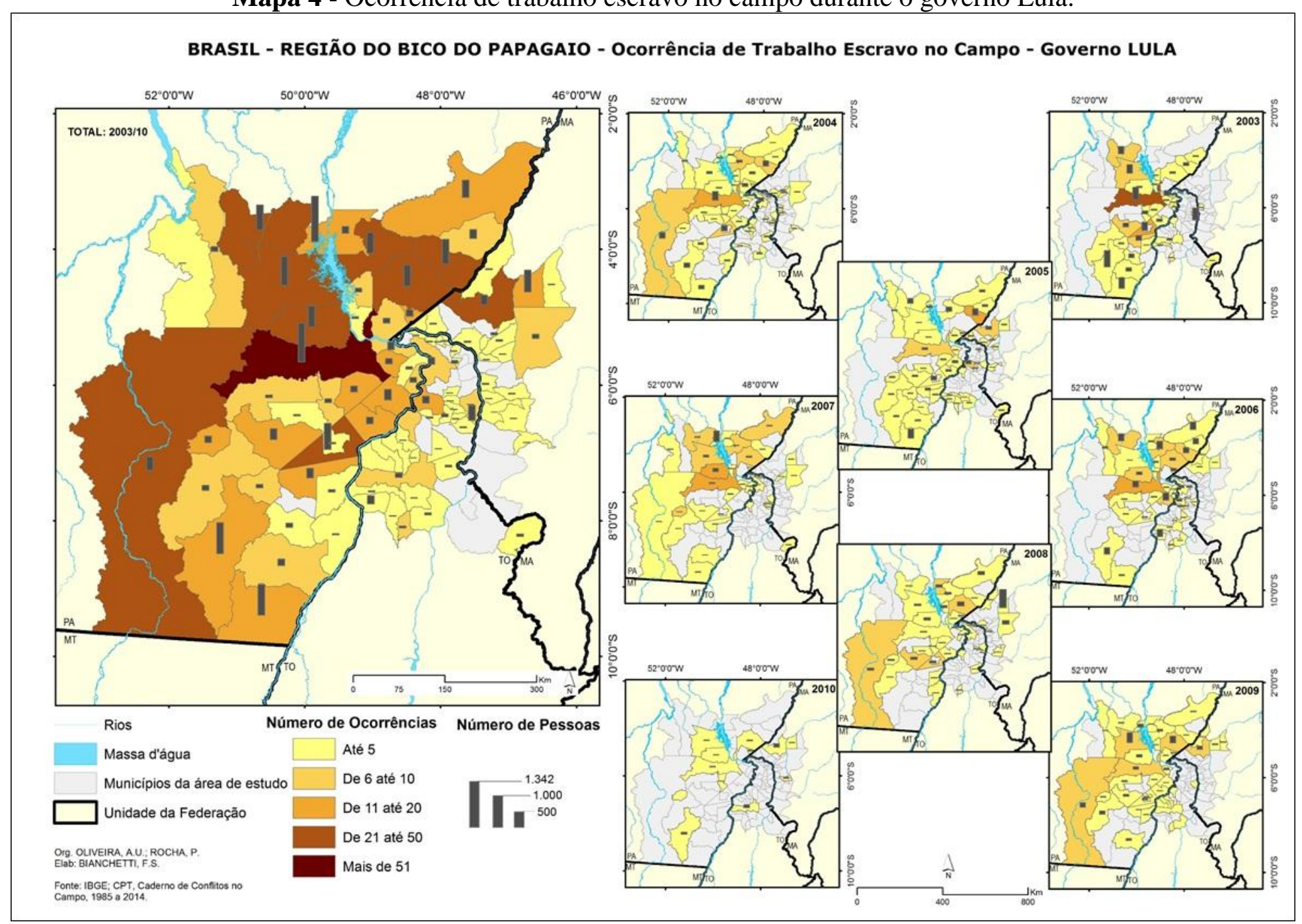


Mapa 5 - Ocorrência de trabalho escravo no campo durante o governo Dilma.

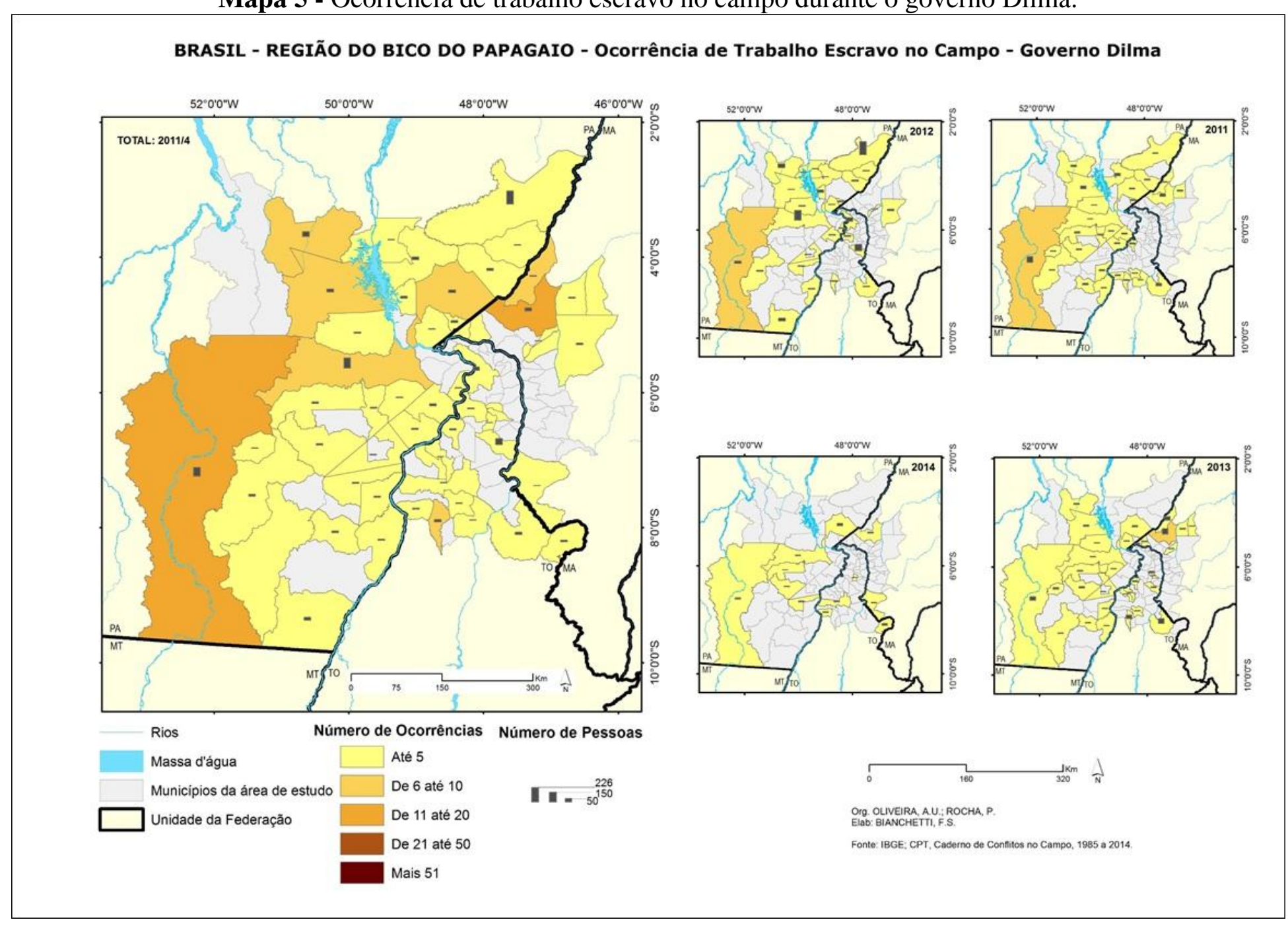


Exemplos emblemáticos: os casos, "Fazenda Rio Cristalino" e "Assentamento 26 de Março"

Os fatores que contribuem para relações trabalhistas da peonagem no Brasil são baseados em escolhas políticas de financiamento especialmente no período ditadura militar. Esse período foi marcado pela persistência da concentração fundiária e pela transformação dos capitalistas urbanos (industriais, financeiros, etc.), no Centro Sul do país, em grandes proprietários de terra, latifundiários, revelando-se, assim, sua condição de classe dos proprietários de terra, com o poder de definir as relações trabalhistas para o campo brasileiro. Conforme Martins (1994)

Quando a superexploração se acentua, em face da necessidade de redução adicional do capital variável, isto é, do dispêndio em salários, a exploração do trabalho facilmente desliza para a peonagem e os mecanismos repressivos da escravidão por dívida. (MARTINS,1994, p. 13)

A situação das classes capitalistas no Brasil revela-se sob perspectivas econômicas mundiais, conferindo-lhes aspectos regionais. Podemos citara questão da Fazenda Vale do Rio Cristalino, na Amazônia, conhecida como Fazenda modelo da Volkswagen, como um dos casos mais famosos do Brasil. Foram muitos investimentos de alta tecnologia, feitos na criação de gado, e a fazenda ostentou durante muitos anos uma mega infraestrutura. Em contrapartida, seus funcionários (peões) viveram em situação de superexploração durante todo período de existência do empreendimento. Foram várias, as denúncias de que a empresa mantinha os peões sob condições de trabalho escravo. Le Breaton (2002) narrou sobre o quão colossal era a infraestrutura da Fazenda Vale do Rio Cristalino:

A Rio Cristalino, propriedade da empresa Volkswagen, era um projeto de fazenda-modelo. E só podia mesmo ser, levando-se em consideração a quantidade de dinheiro nela investido. Mas, não foi apenas o dinheiro, foi a tecnologia de ponta, aliada a muito trabalho e trabalho pesado. (LE BRETON, 2002, p. 187)

Para organizar uma infraestrutura gigantesca como essa, em tão pouco tempo, era necessária mão de obra em demasia, e que custasse o mínimo possível. Aí se encontram as relações mais profundas de exploração do trabalho humano estabelecidas dentro das relações capitalistas:

[...] a escravidão por dívida ou peonagem, é encontrada em diferentes atividades econômicas, organizadas segundo graus extremos e opostos de modernização econômica e técnica. Há economias que ainda seguem padrões do século 19 e até do século 18, como é o caso de setores do 
extrativismo amazônico, em particular o da borracha. E no outro extremo, há atividades, sobretudo as das novas fazendas de criação de gado, na Amazônia, desenvolvidas por empresas modernas, algumas vinculadas a destacados grupos econômicos internacionais. Não estamos, portanto, apenas diante de um fenômeno de persistência de relações arcaicas de trabalho que, à primeira vista, têm sido muitas vezes definidas, impropriamente, como précapitalistas. Pois, o que constatamos é que modernas empresas capitalistas que investem em empreendimentos agropecuários na vasta região da Amazônia brasileira (mais da metade do território de um país com cerca de oito milhões e meio de quilômetros quadrados) rotineiramente tem recorrido à escravidão por dívida em algumas de suas atividades. (MARTINS, 1994, p. $1-2)$

Muito se questionou, no período, sobre o que levaria uma empresa internacional do porte da Volkswagen a se envolver em escândalos relacionados as questões trabalhistas em países do "terceiro mundo". No ABC em São Paulo, os empresários da Volkswagen, revelavam sua condição de classe capitalista no setor automobilístico, e, na Amazônia, revelavam sua condição de classe dos proprietários de terras. É por isso que não há, no Brasil, um setor moderno e um pretensamente atrasado, eles são um só sujeito social revelando duas condições de classe social diferentes: capitalistas de um lado e proprietários de terras de outro (Martins, 1994).

Assim, a participação das grandes empresas de capital nacional e internacional nos setores de agricultura alinharam-se ao ritmo instituído pelas políticas econômicas no Brasil. Em primeiro lugar, porque essas empresas foram incentivadas a dirigir seus investimentos e demais esforços para os setores da agricultura. Em segundo lugar, porque também eram capitalistas, vivendo da exploração do trabalho alheio.

Bastava, então, se aproveitar do sistema de peonagem instituído nas relações de trabalho no campo, para encaixar-se perfeitamente à lógica de acumulação sem fim das empresas. Para compreender a dimensão da questão, basta lembrar Le Breton, narrando a visita do padre Ricardo à fazenda da Volkswagen. O padre questionou sobre os poucos trabalhadores com registros nas carteiras, em detrimento da quantidade de trabalhadores que a fazenda requeria, e o administrador da fazenda explicou que utilizavam o sistema de empreitadas e que a prática era corriqueira em todas as fazendas da região.

No período havia um clima ufanista, construídos pelos governos militares, sobre a ocupação da Amazônia. Ideais de modernidade e de prosperidade eram difundidos, o que tornava a região bastante atrativa, inclusive para os peões e para as demais parcelas da população. Os empreiteiros ("gatos”) cuidavam de construir no imaginário do peão um certo encantamento sobre o lugar. 
$\mathrm{O}$ mito do progresso e da modernidade era amplamente divulgado em todas as instâncias. Assim, para quem vinha de uma vida sem alternativas ou possibilidades de trabalho, viver em um lugar com abundância de trabalho e de dinheiro, segundo o que diziam esses empreiteiros, era mais do que esses peões esperavam para solucionar seus problemas em seus lugares de origem. No entanto, eram muitas as contradições escondidas em acampamentos distantes dos centros administrativos das fazendas. E, como afirmou Le Breton (2002, p. 22), sobre a fazenda Vale do Rio Cristalino:

E bem ou mal, conseguiram milagres, por algum tempo pelo menos Situada no sul do Pará, numa região de serra linda, com muita água, a fazenda cobria uma área de 140 mil hectares e tinha quarenta e seis mil cabeças de gado (a projeção para 1988 era de 106 mil) diferente da maioria das fazendas-fantasmas financiadas pela SUDAM, a Rio Cristalino, havia sido rapidamente implantada e era eficientemente administrada. A primeira árvore havia sido cortada em setembro de 1973 e 22 meses depois haviam plantado pasto suficiente para 2100 cabeças de gado. Em seu material de propaganda, a empresa orgulhava-se de que a presença de uma grande corporação como a Volkswagen traria inúmeros benefícios para a região: a geração de renda, os impostos, cumprimento das leis trabalhistas, carteiras assinadas, registros de empreiteiros e introdução, no mundo do trabalho, de práticas justas e seguras. Padre Ricardo descreveu o complexo administrativo como sendo uma pequena Brasília na Amazônia”. Havia escritórios, garagens, oficinas, laboratórios, um açougue, uma padaria, uma estação meteorológica, um posto de saúde, uma hospedagem para convidados, um clube, uma piscina e vários campos de futebol. A eletricidade era gerada por duas caldeiras a vapor que utilizavam as sobras de madeiras das serrarias. Fabricavam seus próprios tijolos, tinham um supermercado que fornecia leite, carne subsidiados, e supriam gratuitamente os funcionários com hortaliças. Mantinham uma escola primária e uma frota de ônibus, organizavam cursos de alfabetização e de corte e costura para mulheres. O programa de melhoramento para o rebanho utilizava-se de inseminação artificial e criação seletiva; faziam ensilagem, produziam feno, e o gerenciamento do rebanho estava completamente informatizado. Era uma fazenda modelo, ao menos na aparência.

Em suma, a fazenda apresentava uma infraestrutura que nem mesmo as cidades da região possuíam. Isso criou uma expectativa muito grande em torno do projeto. Entretanto, a partir do momento em que as denúncias sobre trabalho escravo, através da imprensa, chegaram aos ouvidos de determinadas autoridades, a pressão política sobre os administradores da fazenda e acionistas da empresa não permitiu que o negócio fosse adiante.

Desta forma, a empresa alemã logo vendeu a fazenda à Matsubara que fez questão de mostrar sua ficha limpa em ocorrências trabalhistas. Porém, nem a Volkswagen e nem a Matsubara conseguiram fazer com que a fazenda produzisse algum lucro. Até que em 1997, a fazenda fosse vendida novamente, porém, desta vez, para os empresários brasileiros Eufrásio 
Pereira Luiz e Marcos Monteiro. Mesmo assim, naquele período, os problemas da fazenda já eram tantos que não houve como recuperá-la Segundo Le Breton (2002), foram muitos os boatos de que os novos donos da fazenda incentivaram "sem terras" a ocupá-la, afim de que o Incra viesse indenizá-los para fins de reforma agrária.

Foi o que ocorreu, no dia 02 de agosto de 1998, quando foi aprovado o decreto de desapropriação que custou 40 milhões, o dobro do preço que os donos haviam pagado por ela. Ao mesmo tempo, debates ocorriam sobre o fato de que os fazendeiros eram acostumados a dar esse tipo de golpe em propriedades localizadas na Amazônia Legal. Em 1999, mil e setecentas famílias de camponeses mudaram-se para a fazenda. Porém, a descoberta de que havia urânio nas terras fez com que o governo federal revogasse a desapropriação, sem tomar nenhum tipo de providência para reassentar os camponeses.

O departamento de Minas e Energia informou que precisava de apenas 4 mil hectares e que o restante da propriedade poderia ser utilizado para fins de reforma agrária. O conflito tomou conta da situação. Os donos reivindicaram e entraram com mandato de reintegração de posse. O Sindicato dos trabalhadores Rurais requereu a desapropriação, garimpeiros, madeireiros e outros camponeses que vinham de todas as partes ocuparam as terras e a violência, juntamente com malária massacrava as pessoas que por ali viviam. O Sindicato de Rio Maria entrou em conflito com o Sindicato de Santana do Araguaia e eis que a situação de conflito perdura até os dias de hoje. (CPT, 1999)

Nesta última década foram várias denúncias de conflitos: mais camponeses acampados aguardando solução por parte do Incra, confrontos e ameaças de morte por parte de madeireiros. Além disso, camponeses de sindicatos e de movimentos sociais também disputam a área.

Atualmente o conflito já envolve, inclusive, o grupo Santa Bárbara que mantém 50 mil cabeças de gado no local. Dos 140 mil hectares, 80 mil foram desapropriados e os outros 60 mil continuam em disputa entre fazendeiros, grileiros e madeireiros. O conflito já resultou em pelo menos 14 mortos e 30 pessoas vivem atualmente ameaçadas. Portanto, não é por ironia que a Fazenda Vale do Rio Cristalino se tornou efetivamente um forte exemplo de modelo da barbárie que o capitalismo moldou no Brasil, incentivando a aliança e a união, em uma só pessoa física ou jurídica, da burguesia capitalista com a classe dos grandes proprietários de terras (latifundiários).

Também, sobre as propriedades com manutenção de trabalho escravo, não podemos esquecer de citar a Fazenda Castanheira, primeira fazenda a ser desapropriada por conta descumprimento da função social, uma conquista dos movimentos sociais, especificamente do 
MST, e também da sociedade brasileira.

Em 1999, como conta Barros (2012) o MST ocupou a fazenda e iniciando o conflito entre sem terras e latifundiários. O Incra iniciou a avaliação técnica após forte pressão do movimento social. No ano de 2000 foi feito vistoria preliminar para aferir sobre a função social da terra. $\mathrm{O}$ relatório indicou que a fazenda era dedicada somente a cria, recria e engorda de bovinos.

A área de pastagem plantada correspondia 65322274 hectares e o rebanho perfazia 5 mil rezes, apenas $25,76 \%$ da fazenda ocupados por florestas nativas, apesar de 50\% estarem averbados em cartório como reserva legal. Os sem-terra ocuparam 81 hectares com cultivos de gêneros alimentícios, arroz, milho, mandioca. Os índices de GUT e GEE não foram considerados satisfatórios para aproveitamento do imóvel, o primeiro alcançou 78,24\% (os mínimos exigidos por lei é $80 \%$ ) e o segundo $100 \%$. Assim, a Cabaceiras se enquadrou na categoria de grande propriedade improdutiva. Contribuíram também para acusar o não descumprimento da função social da terra, os problemas ambientais. Só na área de 3.600 hectares abarcada pelo título de aforamento expedido pelo governo Estadual para a exploração exclusiva da castanha exatos 1.922 hectares de mata haviam tombado irregularmente para ceder lugar as pastagens. (BARROS, 2012, p. 190)

Os setores do IBAMA responsáveis por laudo técnico, também emitiram parecer favorável, após avalição expedida pelo órgão. No entanto, quando tudo parecia a favor da desapropriação, a família Mutran pediu a impugnação da vistoria, que concedeu parecer desfavorável e o INCRA encaminhou outra vistoria que contradisse o parecer anterior.

Nesta nova vistoria, os índices foram modificados apresentando $100 \%$ tanto para o índice de GUT, quanto para o de GEE; também se mostrava total legalidade nas relações trabalhistas na fazenda e negligenciava-se inclusive uma operação do grupo móvel de trabalho do Ministério do Trabalho em 2001 que flagrou trabalhadores em condições análogas à escravidão. E, sobre a área desmatada, o relatório faz menção a 67,73\%, incluindo a área ocupada pelos camponeses sem-terra. Por conta dos dois laudos, o conflito jurídico administrativo se estendeu por dois anos e finalmente veio o decreto de desapropriação da fazenda. Segundo Barros (2012):

A edição do decreto presidencial que declarou a fazenda como área de interesse social para fins de reforma agrária foi subsidiada pela análise feita pela Consultoria Jurídica (Conjur) do Ministério do Desenvolvimento Agrário (MDA). No sumário da informação $n^{0}$ 373" de agosto de 2004, aparece claramente a intenção de fundamentar a edição do decreto com fulcro também no artigo 186, II e III da CF/88. Em face do descumprimento da função social trabalhista e ambiental. (BARROS, 2012, p.193) 
Nesse contexto, a desapropriação da fazenda já não estava mais caracterizada somente pelo critério de improdutividade. As infrações ambientais e trabalhistas estiveram presentes na desapropriação da Fazenda Cabaceiras, uma vitória inédita na luta dos movimentos socioterritoriais. Encerrando-se o processo administrativo, era necessário passar pelo processo judicial e no ano de 2005 o advogado da família Mutran conseguiu junto ao Superior Tribunal, suspender os efeitos do decreto de desapropriação.

Depois de vários impasses judiciais, inclusive para definir o valor administrativo, a pressão dos camponeses sem-terra foi capaz de vencer a teimosia dos latifundiários, pois não recuaram da ocupação da fazenda mesmo em meio a tantas reviravoltas, e, no ano de 2008, a família Mutran desistiu do mandado de segurança. Em 2009, o governo do Estado do Pará entrou na briga, requerendo indenização por conta do título de aforamento expedido em 1959 à família Mutran, pois havia o descumprimento das cláusulas contratuais.

No desfecho final, a Fazenda Cabaceiras foi desapropriada e dividida entre as aproximadamente 330 famílias de camponeses. A fazenda Cabaceiras transformou-se no Assentamento 26 de março, localizando-se no município mais conflituoso da região do Bico do Papagaio, e constituindo-se em mais um símbolo nacional da luta do campesinato contra o latifúndio.

No ano de 2014, em trabalho de campo na fazenda, tivemos a oportunidade de entrevistar alguns assentados. As informações obtidas foram de que muitos dos lotes distribuídos para os camponeses sem-terra, nos últimos anos, foram vendidos para pequenos comerciantes ou para outras pessoas que não possuem o perfil indicativo de reforma agrária. Enquanto alguns camponeses sem terra organizaram seus lotes, tornando-os produtivos, outros atualmente prestam serviço na própria terra que anteriormente era de propriedade dos mesmos.

A seguir, na foto 1, observa-se a fotografia da placa de entrada do assentamento 26 de março, símbolo da maior vitória dos camponeses sem-terra do Brasil na luta contra o trabalho escravo e contra o latifúndio.

A área do assentamento faz limites com outras áreas de fazendas e áreas de assentamento: ao Norte, faz fronteira com as terras das Fazendas Bela Aurora e Mutamba, ambas de José Diamantino, empresário do ramo automobilísticos influente na região; ao Sul, com as terras da Fazenda Boa Esperança e Sítio São José; ao Leste, com o Assentamento Escada Alta e Fazenda Santa Tereza; e ao Oeste, com a Fazenda Pousada, Chácara Vila Boa, 
e Assentamento Piquiá (Santos, 2015). Nas fazendas Mutamba, Boa Esperança, Santa Tereza e no Assentamento Piquiá também foram realizados trabalhos de campo para esta pesquisa.

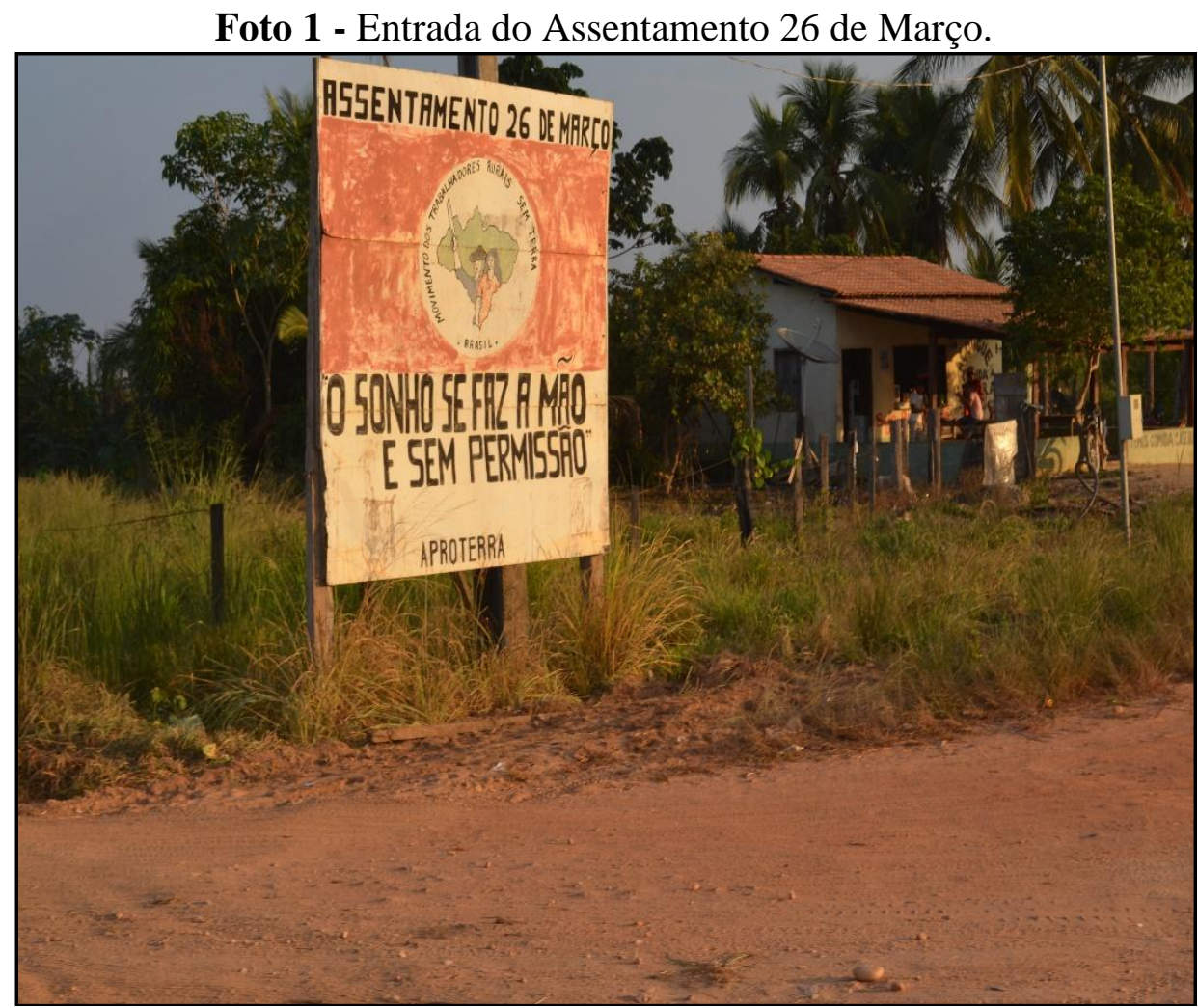

Autora: Chaves, P. Rocha (15/11/2014).

\section{Considerações Finais}

O Artigo 149 do Código Penal define como trabalho análogo ao escravo como aquele em que seres humanos estão submetidos a trabalhos forçados, em condições de superexploração jornadas tão intensas que podem causar danos físicos, em condições degradantes e exaustivas e de restrição de locomoção em razão de dívida contraída com empregador ou preposto. A pena se agrava quando o crime for cometido contra crianças ou adolescentes, ou por motivo de preconceito de raça, cor, etnia, religião ou origem.

Sobre a questão do trabalho escravo na Amazônia, observa-se que regionais da CPT da Amazônia e os agentes de pastoral continuam atuando combativamente ao crime e violência contra os camponeses, suas propriedades e posses. Há ao menos quinze anos a CPT lançou uma campanha cujo lema é "Abra o olho para não virar escravo".

Há denúncias e combate jurídico ao trabalho escravo é hoje uma prioridade. Nos últimos 15 anos, as equipes da Campanha da CPT, atuam em oito estados principalmente 
afetados, acolheram mais de 1.250 denúncias e possibilitaram a libertação de mais de 8.300 pessoas.

"A Campanha da CPT conduz ações coordenadas e planejadas, que têm como foco tanto o que é de caráter emergencial (acolher e amparar as vítimas, proporcionar seu resgate), quanto de caráter estrutural (provocar nas suas vidas mudanças reais, sustentadas em políticas públicas: educação, saúde, interiorização das políticas de geração de emprego e renda, reforma agrária, promover real punição dos responsáveis, inibir empresas e mercadorias que se utilizam do trabalho escravo, anular o lucro-extra oriundo do crime, confiscar a propriedade onde se pratica o trabalho escravo)." (Comissão Pastoral da Terra, 2014)

O que observamos é que os números de ocorrência demonstram a elevação do registro do trabalho escravo. Isto também se deve ser à atenção profunda que a CPTtem realizado no acompanhamento e denúncia desse conflito.

As MPS 458/422 e o Programa Terra Legal, criados para legalizar os latifúndios grilados em terras públicas, também influenciaram para o aumento do trabalho escravo. Com o processo de desterritorialização de posseiros na região por conta dessas medidas, há sempre a possibilidade de ingressarem em trabalhos nas fazendas, pois ficam submetidos à peonagem. O recuo da luta pela terra por parte dos movimentos sociais também contribui para este quadro.

\section{Referências}

BRETON, B, L. A Dádiva Maior: Vida e Morte Corajosas da Irmã DorothStang. Editora Globo: Rio de janeiro, 2008.

Comissão Pastoral da Terra. CENTRO DE DOCUMENTAÇÕES DOM TOMÁS BALDUÍNO. Arquivo dos Textos de Conflitos nos Estados do Pará, Maranhão e Tocantins 1960-2014. Disponível em <http://www.cptnacional.org.br/index.php/publicacoes/cedocdom-tomas-balduino-da-cpt>. Acesso em 03 de março de 2021.

COMISSÃO PASTORAL DA TERRA. Cadernos de Conflitos no Campo. Centro de Documentações Dom Tomás Balduíno. Expressão Popular. SP, 1985-2014.

CARVAlHO, M. Sangue da Terra: A Luta Armada no Campo. Ed. Brasil Debates: São Paulo, 1980.

FERRAZ, S. O Movimento Camponês no Bico do Papagaio - Sete Barracas em Busca de um elo. Editora Ética: Imperatriz, 2000.

FIGUEIRA, R, R. Pisando Fora da Própria Sombra: A Escravidão por Dívida no Brasil Contemporâneo. Editora Civilização Brasileira: Rio de Janeiro, 2004. 
IANNI, O.A Luta pela Terra: História Social da Terra e da Luta pela Terra numa Área da Amazônia. Editora Vozes: Petrópolis, 1978.

Colonização e Reforma Agrária na Amazônia. Editora Vozes: Petrópolis, 1979.

IOKOI, Z, M. Igreja e Camponeses: Teologia da Libertação e os Movimentos Sociais no Campo Brasil e Peru, 1964-1986. Fapesp, 1996.

LUXEMBURgO, Rosa. A Acumulação do Capital. Zahar: Rio de Janeiro, 1976.

KOSTCHO. R. O Massacre dos Posseiros: Conflitos de Terras no Araguaia-Tocantins. $2^{\text {a }}$ Ed. Brasiliense: São Paulo, 1982.

LE BRETON, B. Vidas Roubadas: A Escravidão na Amazônia Moderna. Ed. Loyola: São Paulo, 2002.

MARTINS, J. M. Os Camponeses e a Política no Brasil - As lutas sociais no campo e seu lugar no processo político. Ed. Vozes: Petrópolis, 1981.

. A Militarização da Questão Agrária no Brasil: terra e poder, o problema da terra na crise política. 2a ed. Editora Vozes: Petrópolis, 1985.

Paulo, 1994.

Fronteira: A Degradação do Outro nos Confins do Humano. Hucitec: São

OLIVEIRA, A. U. Integrar para não entregar: Políticas Públicas e Amazônia. Editora Papirus: Campinas, 1991.

Campinas, 1995.

. Monopólio, expropriação e conflitos. 5a ed. Editora Papirus:

SANTOS, L. L. Sujeitos Assentados e sua Relação com a Educação Formal noCampo: Um Estudo de Caso no Assentamento 26 De Março EmMarabá.Dissertação de Mestrado em Dinâmicas Territoriais e Sociedade na Amazônia. Programa de Pós-Graduação em Dinâmicas Territoriais e Sociedade na Amazônia,Marabá, 2015. 130p.

Artigo recebido em 01-10-2020 Artigo aceito para publicação em 20-12-2020 